\title{
Optimizing the polymer waste supply chains based on circular economy
}

\section{Tetyana Skrypko ${ }^{a}$, Nazariy Popadynets ${ }^{b^{*}}$, Tetiana Yakhno ${ }^{c}$, Roman Shulla $^{d}$, Tetiana Vlasenko, Inna Irtyshcheva ${ }^{f}$ and Yevheniia Boiko ${ }^{f}$}

${ }^{a}$ Ivan Franko National University of Lviv, Ukraine

${ }^{b}$ State Institution "Institute of Regional Research named after M. I. Dolishniy of the NAS of Ukraine", Ukraine

${ }^{c}$ Lviv University of Trade and Economics, Ukraine

${ }^{d}$ Uzhhorod National University, Ukraine

${ }^{e}$ Kharkiv Petro Vasylenko National Technical University of Agriculture, Ukraine

${ }_{\text {Admiral Makarov National University of Shipbuilding, Ukraine }}$

\section{H R O N I C L E}

\begin{tabular}{l}
\hline Article history: \\
Received October 27, 2020 \\
Received in revised format \\
January, 25, 2021 \\
Accepted February 252021 \\
Available online \\
February 25 2021 \\
\hline Keywords: \\
Circular Economy \\
Waste Management \\
Recyclables Supply \\
Polymers
\end{tabular}

\section{A B S T R A C T}

\begin{abstract}
The paper shows the results of an empirical study on the optimization of polymer waste supply chains based on the circular economy in Ukraine. The research shows that the main links in the activity should be harmonized for quality and quick optimization of polymer waste supply chains, including the processes of collecting, sorting, treatment, processing, and recycling of resources for maintaining the quality by total cost reduction. The research argues that the circular economy that stipulates the easy processing, recycling, disassembling, and restoring of products replaced the traditional linear model "take, produce, and throw out" that has dominated the economy by now. The study shows that the transformation of supply chains in production ecosystems forms competitive advantages at the enterprises that allow them to be more productive through efficient use of resources.
\end{abstract}

(C) 2021 by the authors; license Growing Science, Canada.

\section{Introduction}

Currently, our planet needs almost a year and a half to restore what is used in a year (the so-called "ecological footprint"). Both governmental and business structures start understanding that available linear systems of the use of resources expose society and enterprises to serious risks. Resources-related restrictions and growing waste and pollution lead to aggravated threats for the wellbeing of humans and from the viewpoint of commercial activity - for competitiveness, profits, and business continuity. To put it simply, there is an urgent need for decoupling or, in other words, the transition to an inclusive and circular economy. The circular economy is an industrial system that is renewable by its designation and intention. The idea is that the polymer products should be used not only one time but repeatedly instead of being thrown out before their value is completely realized. Indeed, only several percentage points of the cost of the initial product are currently costeffective. A linear economy that is based solely on resource exploitation is no longer able to meet modern requirements to quality resource recovery. Thus, the Fourth Industrial Revolution suggests the model of consistent resource recirculation, when the supply chains secure the repeated use of final products and recycling of materials. The National Waste Management Strategy adopted in 2017 (Cabinet of Ministers of Ukraine, 2017) stipulates the reduced volume of solid household waste disposal at landfills from 95\% down to 50\% in 2023 and to $30 \%$ in 2030 . Instead, in 2018-2019, the reduction did not exceed $1.2 \%$ and $1.5 \%$, respectively. Waste disposal in the form it has in Ukraine does irreparable harm to the environment. In general, only one incineration plant "Energy" actually functions in Ukraine (Kyiv). Its capacities allow burning about 250,000 tons of wastes a year if operating continuously. Yet, according to estimations of the Ministry of Communities and Territories Development of Ukraine, the enterprises and population produce over $9 \mathrm{mln}$. tons of wastes.

* Corresponding author

E-mail address: popadynets.n@gmail.com (N. Popadynets)

(C) 2021 by the authors; licensee Growing Science.

doi: 10.5267/j.uscm.2021.2.008 
Only about 600,000 are recycled or burned, while the rest are disposed of at more than 6,000 landfills occupying an area of about 9,000 ha. Meanwhile, 256 of them (4.2\%) are overloaded and $984(16 \%)$ do not meet the environmental safety standards. Out of 543 landfills requiring reclamation, only 74 are actually reclamated (Ministry of Communities and Territories Development of Ukraine, 2019). In particular, a waste sorting station with the capacity to compost up to 5 tons of organic waste a day was opened in Lviv in 2019. Yet, the intention of municipal authorities to build a waste processing plant that would recycle waste by mechanical and biological processing has been remaining unfulfilled for many years. However, the city annually produces about 300,000 tons of waste. Back in 2017, it caused a major waste collapse. Although the economic and social advantages of the circular economy are indisputable, the examples of the waste processing industrial enterprises that ground their supply chains on this paradigm are almost absent in Ukraine. It causes the relevance of this research.

\section{Literature review}

There are currently many scientific approaches to the interpretations of the development of many economic activity types on the grounds of the circular economy. Thus, I.Y. Zvarych (2017) examines the features of circular economy at micro-, meso-, and macro-levels based on the experience of Chinese researchers. On this basis, the processes of global waste management in the context of circular value chains at the mega level are displayed. V. Hurochkina and M. Budzynska (2020) base their research on the grounds of the circular economy concept and its development in the process of resources production and consumption. The authors define the main principles of forming the circular economy and suggest recommendations for the development of the circular economy model in manufacturing. They characterize the current condition of waste management and analyze the waste management indicators in Ukraine. O. Mechynska and V. Hurochkina (2020) suggest the system of waste management at enterprises based on the collection, processing (including restoring, recycling, and redesigning), control for the operations, and maintenance of waste disposal facilities. The authors build the multi-layer hierarchy of waste management and analyze the planning and system approach to waste management and efficient and responsible attitude to resources (from preservation to consumption). The proper attention should be paid to the authors that examine the use of the circular economy elements in various economic activity areas, including the food industry (Irtyshcheva et al., 2020; Pruntseva et al., 2020), agriculture (Yakubiv, 2015, Stroyko et al., 2013; Was et al., 2020), tourism and hotel industry (Yakymchuk et al., 2020; Pavlov et al., 2020; Garasymliuk et al., 2020), and renewable energy sources (Yakubiv et al., 2020; Maksymiv, 2016).

Other researchers prove (Ellen Macarthur Foundation, 2019) that the circular economy requires not only closed material cycles and renewable energy but also operational thinking. Each economic entity (company, person, state) is related to other entities. Together, they form the network where the actions of one player impact the others. To take this into account, it is necessary to consider the short- and long-term consequences when making a choice and the impact of the entire value chain.

The paper aims to research the transformation capacities and advantages of the general ecosystem of the waste processing companies' supply chains in correspondence with the circular economy paradigm.

\section{Materials and Methods}

Optimizing the polymer waste supply chains stipulates integration and synchronization of the key business processes of resources collecting, sorting, primary treatment, and recycling to secure higher quality at reduced total costs. Optimality of the supply chain is defined by meeting the target function and restrictions:

$$
\sum_{i=1}^{m} \sum_{j=1}^{n} X_{i j} Z_{j} C_{j} \rightarrow \min
$$

subject to

$$
\begin{aligned}
& 1-\stackrel{P}{P}=1_{\left(1-P_{j=1}^{P} P_{j}\right) \geq P_{0} \text { if } X_{i j}>0} \\
& \sum_{i=1}^{m} \sum_{j=1}^{n} X_{i j} Z_{j}=Q_{0} \\
& 0 \leq \sum_{i=1}^{m} X_{i j} \leq 1, j=\overline{1, n} \\
& \sum_{i=1}^{m} X_{i j} Z_{j} \leq q_{j}, j=\overline{1, n} \\
& Z_{j} \geq d, j=\overline{1, n} \\
& \sum_{j=1}^{n} X_{i j} q_{j} \geq Q_{0} \text { if not } 0, i=\overline{1, m}
\end{aligned}
$$

requirement to the link reliability;

requirement to supply volume

condition of links inclusion in one chain

restrictions on the capacity of supply links

restrictions on minimum supply

condition of the chain forming 
where $n$ - number of recyclable materials supply channels; $m$ - number of supply links; $Q_{0}$ - nominal order; $P_{0}$ - nominal reliability level; $X_{i j}$ - binary variable of choice that serves to form $m$ links of $n$ channels; $Z_{j^{-}}$optimal plan of link supply; $q_{j}{ }^{-}$ maximum capacity of the link; $C_{j}$ - cost of raw materials in supply in the link.

\section{Results and discussion}

The functioning of supply chains in the circular economy is rather related to optimal natural ecosystems, where each element is organically combined in a closed cycle. In a circular economic environment, products are developed considering the life cycle of material flows. In such a way, additional value is secured in the longest possible time, and the generated wastes are insignificant and consistently reducing. The enterprises develop the integrated supply chains that contribute to more efficient resource management and the creation of new markets. Innovative information and communication technologies and social changes promote such a systemic transformation. Organizations of ecosystems usually approach the goal in two stages: assessment of ecosystem's readiness and its transformation (Fig. 1). Specific and complementary mechanisms are developed at each stage to achieve intermediary goals.

Assessment of ecosystems' readiness is an important starting point for understanding the transformation processes that the producers and their ecosystem partners should undergo to transfer to the circular economy paradigm. A readiness assessment is a fundamental step that allows the company managers to be sensitive to external information, reveal new business opportunities related to the circulation of supply chains, and understand their capacity to accept these opportunities.

Small companies in existing business ecosystems usually hesitate to invest many funds in what is offered by the circular economy due to high initial investment and significant uncertainty of their profitability (Malolitneva, 2019).

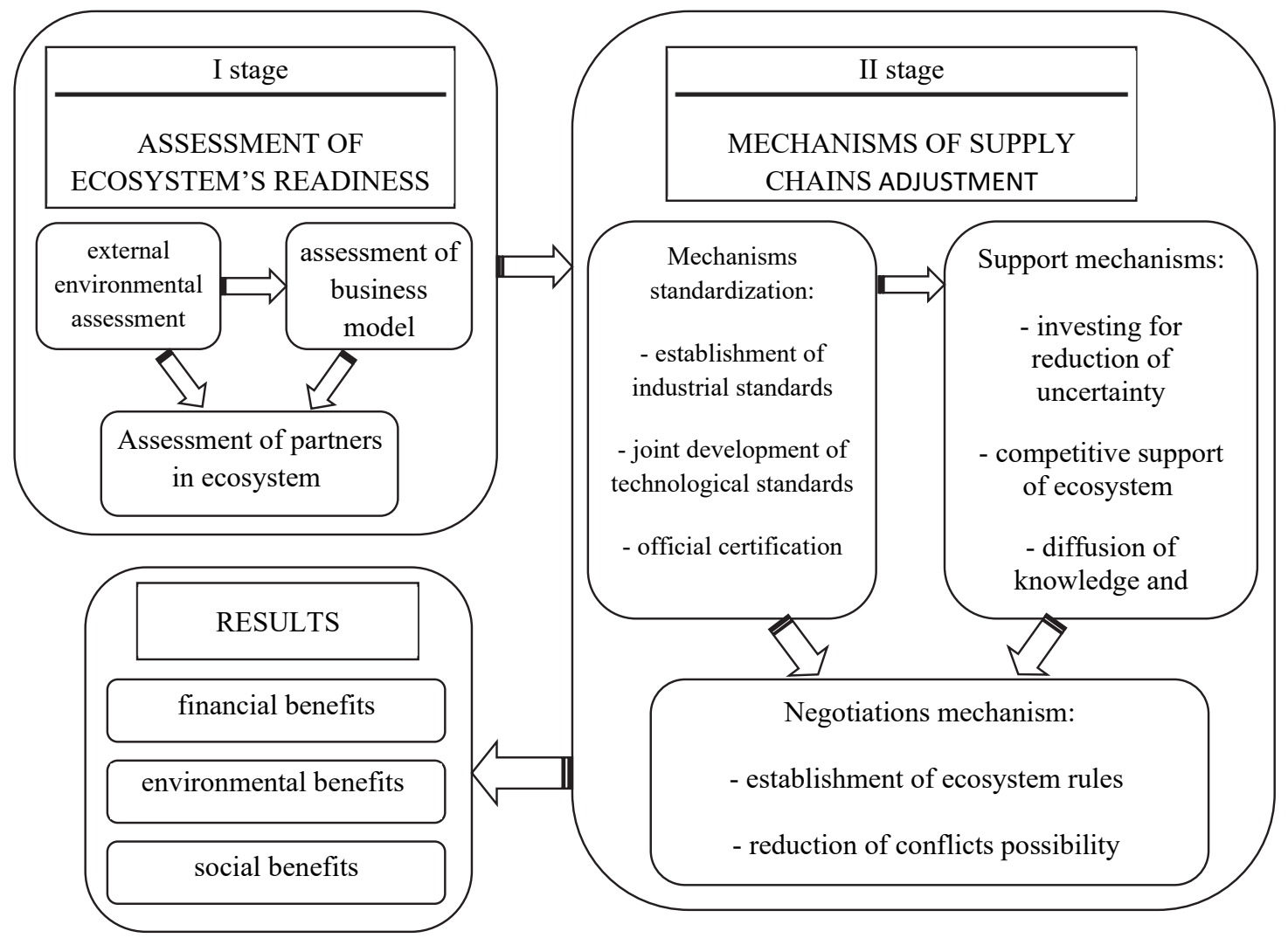

Fig. 1. Technological model of transforming the production supply chains into the circular economy

Source: developed by authors

Investment can be encouraged by granting economic benefits to such enterprises. Respective agreements can impact mutual dependence, therefore, all involved enterprises have a clear distribution of roles in supply chains and common benefits. An opportunity for coordinated integration of endeavors of separate supply chain links is an advantage of the circular organization of supply chains for the achievement of strategic development goals by manipulations with flows of materials, information, and finance. The implementation mechanism stipulates the support of innovative developments and processes by partners: competencies development, automation of supply chains management, adjustment of circular components of products (Table 1). Main volumes of industrial waste are generated in mining and mining and chemical industry, engineering and metal processing industry, forestry and wood processing industry, energy, chemical, petrochemical, and adjoining industries, food industry, and consumer industry. The annual volume of industrial waste generation is $419.2 \mathrm{mln}$. tons and the volume of accumulation in specifically allocated spots and objects is 13.27 billion tons. The lack of an efficient system 
of packaging waste logistics leads to the annual loss of essential resource capacity for the processing industry in the form of paper and cardboard waste of 0.5-0.6 mln. tons, glass - $1 \mathrm{mln}$. tons, polymers $-0.6 \mathrm{mln}$. tons. Considering the human living activity as a kind of display of supply chains functioning, it is worth mentioning that generation of over $250-300 \mathrm{~kg}$ of household waste a year is the end link of consumption, 39\% of which accounts for food, about $13 \%$ for paper and cardboard, and over $11 \%$ for polymer waste (Fig. 2).

Table 1

Transformational business models of circular supply chains

\begin{tabular}{lll}
\hline \multicolumn{1}{c}{ Business models } & & \multicolumn{1}{c}{ Circular features of supply chains } \\
\hline Cyclic supply chains & - & use of self-decomposing biomaterials; \\
Resource processing & - & agreements with suppliers of eco-friendly raw materials on waste return for further processing \\
& - & processing of non-recyclable products; \\
Exchange platforms & - & development of infrastructure of waste collecting, sorting, and processing \\
& - & prolonging the products' life cycles; \\
Prolonging the products' & - & reduced non-recyclables production \\
life cycles & - & domestic investment in new technologies; \\
& - & foreign direct investment and technology import; \\
& - & cooperation between business and scientific centers \\
A product as a service & - & package services that include product-support services; \\
& - & producer's responsibility for products disposal after life cycle is completed; \\
& - & forming of closed supply chains \\
\hline
\end{tabular}

Source: developed by authors

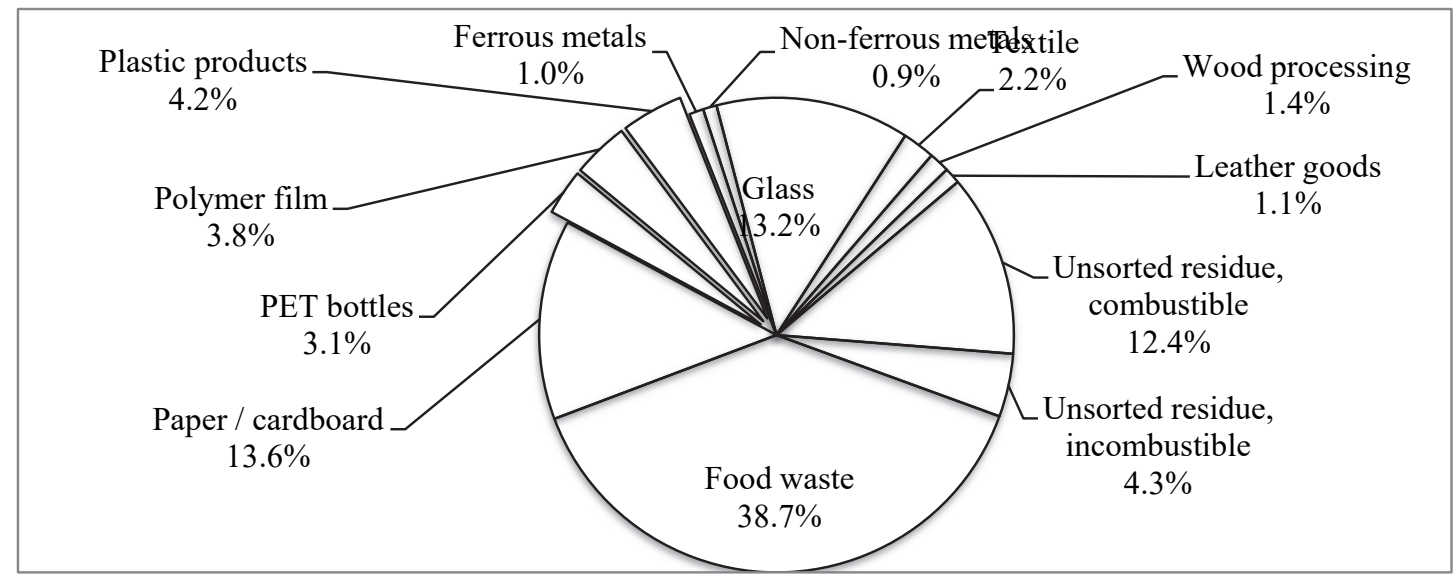

Fig. 2. Waste distribution by types in Ukraine in 2019.

Source: developed by authors on the basis of (DP "Scientific-Research and Design-Engineering Institute of Municipal Economy", 2020)

In this regard, the living activity processes do not differ much from the functioning of the production or other economic structures that annually generate tons of waste. The introduction of a new link into these supply chains - recycling of polymers - can both improve the environmental situation and bring substantial economic advantages for processing links. Thus, the production cycle of PET bottles, which are nowadays the main source of polymer pollution of Ukrainian territories, stipulates the use of about $250 \mathrm{ml}$ of oil production per unit of output. Flakes and recycled granulated polymer production from used bottles allow achieving almost zero waste closed cycle (Fig. 3).

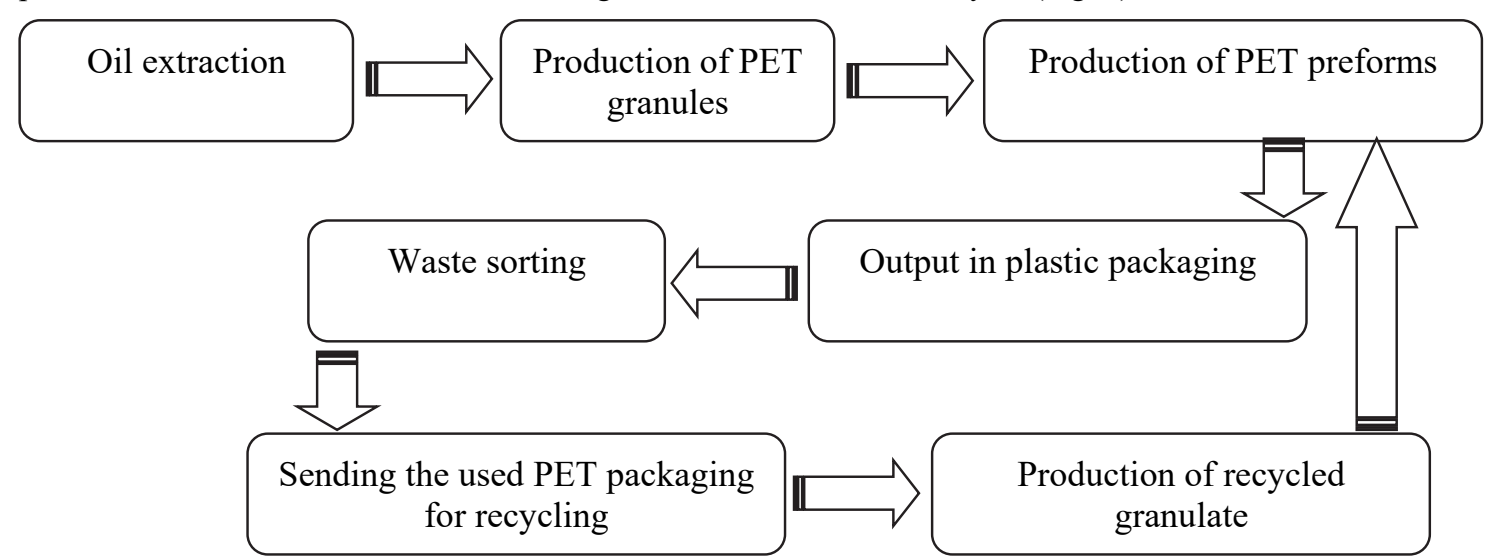

Source: developed by authors

Fig. 3. Closed supply cycle for PET packaging recycling 
The described model completely agrees with the EU strategy for waste processing maximization in the circular economy (European Commission, 2019), yet no more than 10\% of used polymer products undergo recycling. Polymer waste is a considerable pollutant for the environment because its decomposition processes last for about 100 years. Polymers that contain the chlorine particles damage groundwaters, and their ability to actively release methane leads to global warming. A wide range of goods can be produced of polymer materials: PET bottles (polyethylene terephthalate, PET) for cold drinks, dairy products, cosmetics, and household chemicals; semi-rigid packaging made of high-density polyethylene (HDPE) bottles for dairy products and juices, bottles for shampoos, containers for food, disposable tableware, garbage bags; materials of polyvinyl chloride (PVC) - to package granulated products, store vegetable oils, in chemical industry to produce containers for technical fluids, and produce windows, toys, tubular products, stretch ceilings, and shutters, etc.; materials of low-density polyethylene (LDPE) - for flexible containers, films for food industry, and bottles for household chemicals, etc.; materials of polypropylene (PP) - for containers for food freezing, reusable and disposable tableware for hot dishes, baby bottles; materials of polystyrene (PS) - to produce coffee containers, disposable tableware, containers for fast food and storage of fruits, meat, and fish products (Pohrebennyk et al., 2019).

By the level of processing complexity, the polymer waste is divided into materials with good properties (clean, sorted, possible recycling of up to $90 \%$ of feed stock), average (requiring sorting and preliminary treatment, causing a supply chain to lose additional links, possible recycling of $20-30 \%$ of feed stock), and complex (heavily contaminated and / or mixed low-polymer waste, recycling is inexpedient).

Chemical enterprises can be prospective consumers of recycled polymer products. It is expedient to be used in the production of nonwoven fabric, building materials, and household plastic products, etc. Waste sorting infrastructure has been developing rapidly in Ukraine lately. It stipulates the initial separation of PET raw materials (Zvarych, 2019). Yet, existing recycling capacities remain to be low-used: market capacity is estimated at 350,000 tons of plastic but only 180,000 tons of polymer waste are actually processed annually (Ministry of Communities and Territories Development of Ukraine, 2019). The deposit system is an efficient system to stimulate the respective waste separation. In this case, the commercial price of the used plastic containers should exceed the market one. Yet, it can make a product more expensive by increasing consumer expenditures. Therefore, it is hardly applied. The actual commercial proposal for this type of recyclables ranges within UAH $3 \pm 0.5$ per $1 \mathrm{~kg}$.

Solid household waste contains up to $40 \%$ of the materials valuable for recycling (Hamad et al., 2013). However, waste sorting in Ukraine is not arranged sufficiently. It goes mostly to general containers, which leads to secondary contamination of prospective recyclables, reduction of their value by $5-10 \%$, and inclusion of an additional link of raw materials disinfection in the supply chain.

The absence of payment for packaging processing for industrial producers is another problem. It makes the link of recyclables collection and processing more expensive compared to European practice where the cost of packaging processing is included in the price of products in advance (Herasymchuk, 2019). Therefore, there is a conflict of interests of economic entities in the supply chain because a large number of its participants causes the emergence of opposing interests. The cost of raw materials for further processing grows while growing purchase price makes processing enterprises cancel their purchase due to more attractive market proposals for import alternatives. The falling price can lead to the situation when the population rejects their supply to the recyclables collection points. The described conflict of interests has caused even a certain deficit of domestic recyclables for Ukrainian processing enterprises (Table 2).

Table 2

Load indicators of Ukrainian recycling enterprises in 2019

\begin{tabular}{lcccc}
\hline \multicolumn{1}{c}{ Indicator } & Paper-cardboard waste & Polymers & PET bottles & Waste glass \\
\hline Number of processing enterprises, units & 17 & 39 & 19 \\
Production capacities, thous. tons & 1200 & 260 & 77 \\
Use of available capacities, $\%$ & 92 & 65.4 & 800 \\
Load, thous. tons & 1104,5 & 170 & 65 \\
including imported recyclables, thous. tons & 392.3 & 53.4 & 50 & - \\
\hline
\end{tabular}

Source: calculated by authors based on the data (Ukrvtorma, 2020)

The parameters of the supply chain for PET bottles processing are highly changing also due to commercial fluctuations of demand and supply. A growing number of alternative suppliers of a resource leads to its falling cost, and therefore - the declining interest of sorting stations in its separation, treatment, and further sales to processing enterprises. Reduced planned deliveries urge companies to plan alternative sources of polymer waste, in particular, to develop the production of industrial packaging, plastic bags, or plastic products. Meanwhile, production expansion increases the risk of losing control over the supply chains because of the emergence of many new links. Namely, companies producing apparel, children's toys, and industrial textiles can become the new end links for the conversion of polymer waste into the fiber.

SWOT matrix allows forming the plan of managerial actions to improve the supply chains (Fig. 4). The analysis provides a clear understanding that the profitability of polymer waste recycling is achieved due to accessibility and low cost of raw materials and low competition and quality of obtained products. Meanwhile, the considerable dependence on the consumer market at the background of social rejection of the polymer waste disposal problem forms the central problem of recycling. 


\begin{tabular}{|c|c|c|c|c|c|}
\hline & & \multicolumn{2}{|c|}{ Opportunities } & \multicolumn{2}{|c|}{ Threats } \\
\hline & & $\begin{array}{l}\text { Low } \\
\text { competition }\end{array}$ & $\begin{array}{l}\text { Accessibility } \\
\text { and low cost of } \\
\text { raw materials }\end{array}$ & $\begin{array}{l}\text { Demand } \\
\text { fluctuations } \\
\text { and prices for } \\
\text { recyclables }\end{array}$ & $\begin{array}{c}\text { Low social } \\
\text { understanding } \\
\text { of the polymers } \\
\text { disposal } \\
\text { problem }\end{array}$ \\
\hline \multirow{2}{*}{ Strengths } & $\begin{array}{c}\text { Flexible competitive } \\
\text { tariffs }\end{array}$ & \multirow{2}{*}{\multicolumn{2}{|c|}{ Strategic priority }} & & \\
\hline & High profitability & & & & \\
\hline \multirow[b]{2}{*}{ Weaknesses } & $\begin{array}{c}\text { Considerable } \\
\text { dependence on } \\
\text { consumer market }\end{array}$ & & & \multirow{2}{*}{\multicolumn{2}{|c|}{ Central problem }} \\
\hline & $\begin{array}{c}\text { Insufficient } \\
\text { development of } \\
\text { recyclables processing } \\
\text { market }\end{array}$ & & & & \\
\hline
\end{tabular}

Fig. 4. SWOT analysis of the efficiency of polymer waste recycling supply chains

Source: developed by authors

Contractual relations with partners in supply chain management should be based on understanding that traditionally each link is oriented at maximizing profits while minimally considering the impact on the efficiency of partners in the chain. Therefore, while planning the supply base for the entire chain, a processing enterprise should specify the features of cooperation (price, periods and volumes of supplies, distribution of logistical and financial risks) for a long-term period, which helps investment for the development of the enterprise. Thus, the inclusion of outsourcing in the supply chain helps to transfer the processes of collection, primary treatment, transporting, packaging, and storage of obtained processed products to the external company.

Forming the polymer waste recycling supply chain actually becomes the task of choosing the most economically beneficial promotion channels. Their reliability is secured by compliance with the requirements to functional parameters of raw materials and fulfillment of contracts by end links of supply/consumption (Fig. 5).

Referring to the reliability of certain links of the general polymer waste supply chain, it is worth mentioning that in correspondence with the circular economy principles, the decreasing adverse impact on the environment is the main task of recycling. Therefore, the distribution of tasks on limited waste accumulation should take place in all links (Table 3).

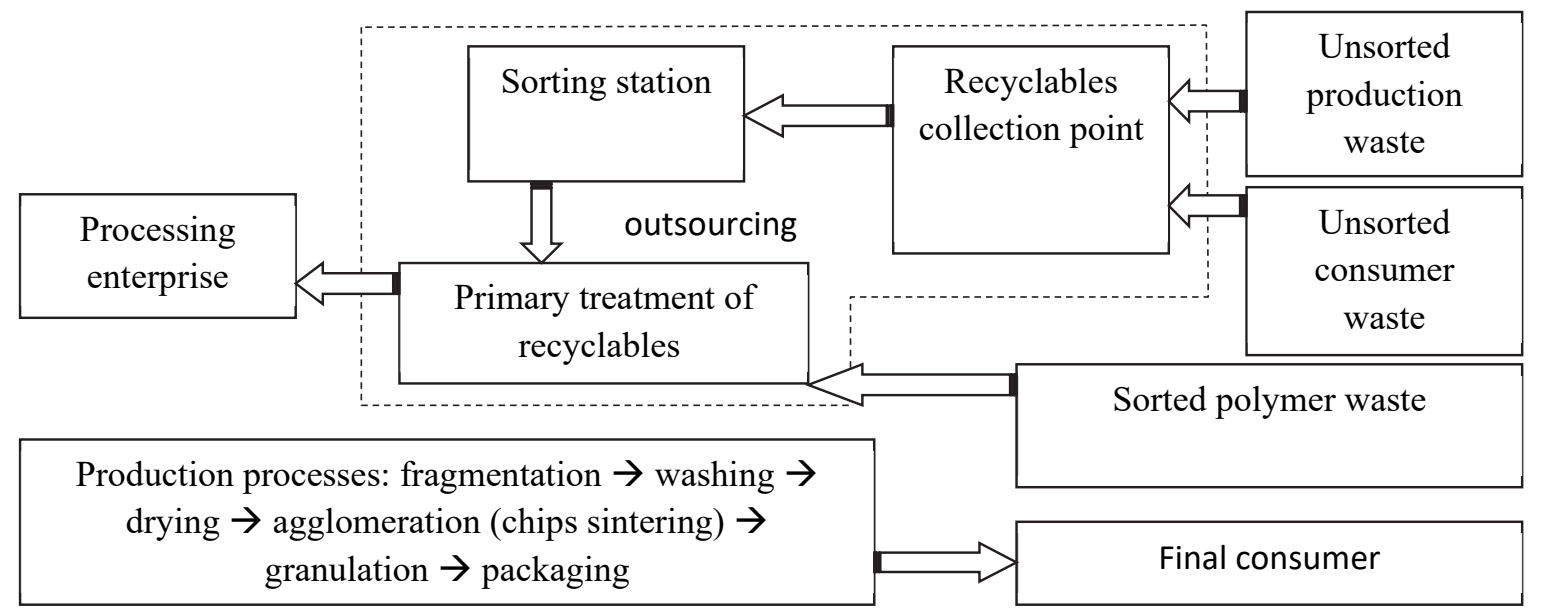

Fig. 5. Model of structural reliability of the polymer waste recycling supply chain with included outsourcing Source: developed by authors 
Table 3

Distribution of responsibility for decreasing the waste between the links of the polymer waste supply chain

\begin{tabular}{|c|c|}
\hline Supply chain links & Measures securing the waste decrease \\
\hline Packaging producers & $\begin{array}{ll} & \text { development and introduction of materials-efficient technologies; } \\
\text { - } & \text { development of reverse packaging production technologies; } \\
\text { - } & \text { use of recyclables. }\end{array}$ \\
\hline $\begin{array}{l}\text { Industrial producers that use } \\
\text { polymers for packaging }\end{array}$ & $\begin{array}{l}\text { - establishment of circulation of recyclable packaging (containers); } \\
\text { - } \quad \text { financial participation in the organization of used materials collection. }\end{array}$ \\
\hline Retail companies & $\begin{array}{l}\text { - } \quad \text { organization of multiple-use containers return; } \\
\text { - } \quad \text { organization of polymer waste collection. }\end{array}$ \\
\hline Final consumers & $\begin{array}{l}\text { - } \quad \text { sorting of used waste with further stacking into containers; } \\
\text { - } \quad \text { delivering the sorted waste to collection points. }\end{array}$ \\
\hline Sorting stations & $\begin{array}{l}\text { - } \quad \text { organization of collection and sorting of polymer waste; } \\
\text { - } \quad \text { organization of preliminary treatment of polymer waste. }\end{array}$ \\
\hline Processing enterprises & $\begin{array}{l}\text { - } \quad \text { waste processing into quality recyclables; } \\
\text { - } \quad \text { use of waste as raw materials for further processing; } \\
\text { - } \quad \text { production from polymer recyclables; } \\
\text { disposal of non-recyclable waste residues. }\end{array}$ \\
\hline
\end{tabular}

Source: developed by authors

Meeting the needs of final consumers of recyclables should be adjusted with maximized profitability of processing in the supply chain, which requires the reduced level of logistic costs. The measures on polymer waste reduction at all supply chain links stipulate the extended responsibility model. In this context, it is worth addressing the concept of continuous resource circulation. Designing the closed supply chains and a complex approach to processing the recyclables contribute to concentrating the entire production chain cycle in one processing enterprise. As a result, the non-processed residues bound to be disposed of at landfills will decrease substantially. Reliable packaging of pressed residues will secure their isolation from the precipitation impact, preventing the release of highly toxic agents into the environment.

\section{Conclusion}

Transformation of production ecosystems supply chains can give the processing enterprises various competitive advantages. Namely, the enterprises achieve higher productivity, better resource exploitation, better ecosystem transparency, growing market, and growing financial benefits. There are various options of how strictly the companies can manage relationships with other supply chain participants. Such a differentiated approach will contribute to the establishment of more flexible relationships between various supply chain objects, improving their management efficiency. The inclusion of the circular economy paradigm into the model creates opportunities for sustainable development. Further research should address the analysis of transformation capacities of a big range of competitive parties and stakeholders in terms of their involvement in the implementation of their business models in the circular economy.

\section{References}

Cabinet of Ministers of Ukraine (2017). On adopted 2030 National Waste Management Strategy in Ukraine: Resolution № 820-r as of 8 November 2017. Retrieved November, 12, 2020 from: https://zakon.rada.gov.ua/laws/show/820-2017$\% \mathrm{D} 1 \% 80$ TText

DP "Scientific-Research and Design-Engineering Institute of Municipal Economy" (2020). Resource efficiency of industrial companies. Online event on 5 November 2020. Retrieved November, 15, 2020 from: https://ispn.kievcity.gov.ua/HelpInfo/News/NewsOne.aspx?ID=231

Ellen Macarthur Foundation (2019). What is the circular economy? Ellen MacArthur Foundation. 2019. Retrieved November, 18, 2020 from: https://www.ellenmacarthurfoundation.org/

European Commission (2019). Circular economy. Retrieved November, 15, 2020 from: https://ec.europa.eu/growth/industry/sustainability/circular-economy_en

Garasymliuk, M., Popadynets, N., Skrypko, T., Topchiy, O. (2020). Analysis And Modeling Of The Impact Of Factor Determinants On Functioning Of Hotel Economy In Ukraine Studies of Applied Economics: The Recent Economic Trends and their Impact on Marketing, 38-3(1). https://dx.doi.org/10.25115/eea.v38i3\%20(1).3976

Hamad, K., Kaseem, M., \& Deri, F. (2013). Recycling of waste from polymer materials: An overview of the recent works. Polymer Degradation and Stability, 98(12), 2801-2812. doi:10.1016/j.polymdegradstab.2013.09.025

Herasymchuk, V.H. (2019). Strategy for plastics in the circular economy: boosting business, reducing waste. Economic Bulletin of NTUU "KPI", 1, 31-41.

Hurochkina, V., \& Budzynska, M. (2020). Circular Economy: Ukrainian Realities and Opportunities for Industrial Enterprises. Economic Journal. Series: Finance, Accounting, Taxation, 5, 52-64. https://doi.org/10.33244/26175932.5.2020.52-64

Irtyshcheva, I., Stehnei, M., Popadynets, N., Danylo, S., Rogatina, L., Bogatyrev, K., Boiko, Y., Hryshyna, N., Ishchenko, O., \& Voit, O. (2020) Business Process Management in the Food Industry Under the Conditions of Economic Transformations. Management Science Letters, 10(14), 3243-3252. doi: 10.5267/j.ms1.2020.6.014 
Maksymiv, Y.V. (2016). Reporting as an important tool in ensuring interaction between stakeholders. Actual Problems of Economics, 178(4), 304-310.

Malolitneva, V.K. (2019). Circular public procurement as a tool to achieve sustainable development goals. Economy and law, 2(53), 84-94. https://doi.org/10.15407/econlaw.2019.02.084

Menshynska, O. M., Hurochkina, V. V. (2020) Monitoring of emergence properties of development industrial enterprises conditions strengthening integration processes. Journal of Hmelnytsk National University. Economic Sciences, 2(1), 178-187. doi: 10.31891/2307-5740-2020-278-1-31

Ministry of Communities and Territories Development of Ukraine (2019). Ukrainian territorial communities are increasingly implementing waste sorting. Retrieved November, 13, 2020 from: https://www.minregion.gov.ua/napryamki-diyalnosti/zhkh/terretory/use-bilshe-ukrayinskih-teritorialnih-gromadvprovadzhuyut-sortuvannya-smittya/

Pavlov, K., Pavlova, O., Korotia, M., Horal, L., Ratushniak, I., Semenov, M., Ratushniak, L., Shapovalov, Y., Anastasenko, S., Hryhoruk, I., \& Popadynets, N. (2020). Determination and Management of Gas Distribution Companies' Competitive Positions. In: Mrugalska B., Trzcielinski S., Karwowski W., Di Nicolantonio M., Rossi E. (eds) Advances in Manufacturing, Production Management and Process Control. AHFE 2020. Advances in Intelligent Systems and Computing, 1216, 302-309. Springer, Cham. doi.org/10.1007/978-3-030-51981-0_38

Pohrebennyk, V.D., Koval, I.I., \& Dzhumelya E. A. (2019). Trends of development of methods and management systems of waste. Scientific Journal of NLTU, 29(1), 78-82.

Pruntseva, G., Popadynets N., Barna, M., Stetsiv, I., Stetsiv, I., Yakubiv V., Shymanovska-Dianych, L., Fedotova, Y., Karpiak, M., \& Hryhoruk, I. (2021) The impact of governance on agricultural production as an exclusive factor of the country's food security. Accounting, 7(1), 75-80. doi: 10.5267/j.ac.2020.10.012

Stroyko, T., Irtyshcheva, I., \& Stehney, M. (2013) Public regulation of integration systems development in agri-food sphere of Ukraine under globalization. Actual Problems of Economics, 3,125-134.

Ukrvtorma (2020). Commercial proposals. Retrieved November, 18, 2020 from: http://ukrvtorma.com.ua/comm-offer.html

Yakubiv, V. (2015). Accounting and analytical methods of diagnostics improvement for enterprises' organizational development. Economic Annals-XXI, 3-4(1), 68-71.

Yakubiv, V., Panukhnyk, O., Shults, S., Maksymiv, Y., Hryhoruk, I., Popadynets, N., Bilyk, R., Fedotova, Y., \& Bilyk, I. (2020). Application of Economic and Legal Instruments at the Stage of Transition to Bioeconomy. In: Ahram T. (eds) Advances in Artificial Intelligence, Software and Systems Engineering. AHFE 2019. Advances in Intelligent Systems and Computing, 965, 656-666. Springer, Cham. doi.org/10.1007/978-3-030-20454-9_64

Yakymchuk, A., Valyukh, A., Diugowanets, O., Bilyk, R., Pavlov, K., Pavlova, O., Batkovets, N., Popadynets, N., \& Hryhoruk,I. (2020). Public Administration and Economic Aspects of Ukraine's Nature Conservation in Comparison with Poland. In: Kantola J., Nazir S., Salminen V. (eds) Advances in Human Factors, Business Management and Leadership. AHFE 2020. Advances in Intelligent Systems and Computing, 1209, 258-265. Springer, Cham. https://doi.org/10.1007/978-3-030-50791-6 33

Zvarych, I. Y. (2017). Circular economy and global waste management. European Economy Journal, 16(1), 41-57.

Zvarych, I.Y. (2019). Implementation of the EU action plan in the circular economy. Scientific Journal of Uzhorod National University. Series: International economic relations and the global economy, 25(1), 93-98.

Was, A., Sulewski, P., Krupin, V., Popadynets, N., Malak-Rawlikowska, A., Szymanska, M., Skorokhod, I., \& Wysoki'nski, M. (2020). The Potential of Agricultural Biogas Production in Ukraine - Impact on GHG Emissions and Energy Production. Energies. 13 (5755), 1-20. doi:10.3390/en13215755

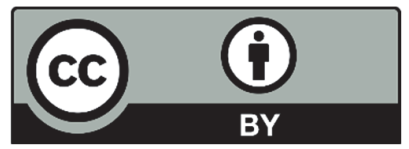

(C) 2021 by the authors; licensee Growing Science, Canada. This is an open access article distributed under the terms and conditions of the Creative Commons Attribution (CC-BY) license (http://creativecommons.org/licenses/by/4.0/). 